character in the population-immediate action could be called for.

A number of the services suggested could be offered on an economically self-supporting basis.

To desire and seek truth and embody its wisdom in a plan of life is surely an ideal which will call out man's highest endeavour.

${ }^{1}$ Local Government Directory, 1941, pp. 231-243. This excludes Home Office Approved Schools. . (Annual Report of Ministry of Home Office Approved Srhool
Health, 1938-1939, p. 202.)

'Gen. Statistical Review, 1938. Table 1, p. 1.

" "The Social Distribution of University Edncation" by Prof. Major Greenwood. (J. Roy. Statistical Soc., 102, pt. III, 368 (1939)).

" "Labour Conditions in Northern Rhodesia", by Major G. Orde Browne. Colonial C.M.I. No. 150. (H.M.'Stationery Office. 28. net), $24,25$.

s "Labour Conditions in the West Indies", by Major G. St. J. Orde Browne. (H.M. Stationery Office, 1939), p. 70 .

- This. of course, excludes the medical and surgical research opportunities-these with few exceptions are directed to disease. not even to preventive medicine or to the maintenance and promotion of positive health. Dr. Frost, medical secretary of the British Social Hyciene Council (in a personal communication) analysed the duta available in relation to the Universities of London, Liverpont, Manchester arid Birmingham. The distribuLondon, Liverpon, Manchester and Birmingham. The distribution of exhibitions, scholarships, st udentships. fellowships, medals, prizes and research grants is as follows: divinity, 5 ; medicine (including dental surgery), 64 ; history and law, 36 ; art and arrhitecture, 24 ; music, $1 ;$ teaching, 6 ; classics, 8 ; foreign languages (including phonrtics). 27 ; journalism, 3 : literature, 17 geography and geology, 6 : mining, metallurgy and engineering, 42 ; archæology, 2; chemistry, physics, science, 51 ; mathematics and statistics, 12; physiology, 10; social science and economics, 22; commerce, 8; genetics or psychology, 3 philosophy, 2; zonogy or botany, 5; open, 43 ; speciticall , NATURE, 148, 787 (December 27, 1941).

\section{IMPACT OF THE PHYSICAL SCIENCES ON SOCIETY}

\section{BY Prof. J. A. CROWTHER \\ University of Reading}

$\mathrm{T}$

H.E cause célebre of the Inquisition $v$. Galileo Galilei has often found mention in the columns of Nature. In every recrudescence of the old controversy between science and religion it is as certzin to crop up as King Charles's head in Mr. Dick's memorial, or as the burning of coffee berries at Costa Rica in a certain type of political argument, and with about equal relevance. The opprobrium showered on the instigators of that famous trial has been, perhaps, somewhat excessive. Their methods must be condemned-truth is not to be suppressed-but in their recognition that scientific discovery raises problems of vital import to society as a whole the Jesuit Fathers showed an insight into the potentialities of science which it would have been well if it had been shared by the statesmen of the past hundred years or so. The impact of discoveries in the physical sciences upon a society unprepared to receive them has led to an enormous increase in material wealth, but at the same time has raised a host of social, economic and political troubles from which the world is suffering to-day.

Though deplorable, it is not surprising that the farreaching consequences of the work of the natural philosopher were not foreseen either by philosopher or politician. In spite of the often repeated statements to the contrary from upholders of a certain political philosophy, the discoveries in physics which have done most to change the face of society were not made with the conscious desire of meeting the material needs of mankind. Michael Faraday did not begin the researches which led to the discovery of electro-magnetic induction and issued in the present electrical era, in an attempt to improve on the Bunsen cell, nor did Sir J. J. Thomson discover the electron with the object of enabling the world to listen in to the B.B.C. Without in any way depreciating the painstaking and often brilliant work of the applied physicist, who, for very little reward, harnesses the principles of physics to the benefit-or destruction- of mankind, it remains true that the great revolutionary advances have been made by men who have had no motive except the undowered pursuit of truth in the natural world. The man who seeks for the love of the search will discover more than a man who is just looking for his collar-stud. Paradoxically enough, the first requisite for any further great progress in the application of science to the welfare of society is that the man of science shall be able to pursue his researches in absolute freedom from economic motive or State direction. Science in fetters will ultimately fail even in its ancillary duties as the handmaid of industry.

This being so, it is important if the disadvantages of the laisser-faire policy of the past are not to be perpetuated, that steps be taken now in preparation for dealing with the discoveries pregnant with new possibilities which are sure to come along. Research is always most difficult, though often most rewarding, in the no-man's-land which lies between the different sciences. It is likely to prove exceptionally difficult when the sciences differ as widely as physics and sociology : yet a liaison between the two is the most hopeful way of ensuring that the vast potentialities which the physicist is ever laying bare should be utilized for the welfare, and not to the hurt, of mankind. There is inevitably a pause, longer or shorter, between the discovery of a new principle, and its application. It is in this interval that direction and control can most easily be exercised. An excellent example of an opportunity happily grasped in time is provided in the control of broadcasting in Great Britain by the creation of the British Broadcasting Corporation. Instances where the opportunity was not seized may be left to the reader's own judgment.

The problems facing any central organization for sociological research are not, however, merely those of procuring a greater use of the unfolding powers revealed by the physicist. There are some possibilities which it might be wiser not to develop, and others where the application might be wisely delayed until necessary adjustments in our social organization had been made. An illustration, on a small scale, is provided by modern traffic conditions in our great cities. It is reported that the late Marquis of Salisbury would order his carriage and pair to await him in Downing Street ten minutes before his train for Hatfield was due out at King's Cross. It is doubtful whether a Secretary for Foreign Affairs just before the War could have cut the time of the journey so fine, although his modern car had some ten times the top speed of the Marquis's equipage. A more serious example of 'bad-timing' is provided by the whole history of the industrial era.

Almost every material problem is essentially a question of the proper utilization of energy; and practically every payment we make is directly or indirectly a payment for energy. Matter itself is indestructible, and though not unlimited in quantity, more than ample for our needs. Man's ability to gratify his desires on the material plane is limited only by the energy which he can control. It is for this reason that physics, which is the science concerned 
with the study of energy in all its protean forms, has played so large a part in the material developments of the past hundred and fifty years. Until the begin. ning of the scientific era man had to rely for his supply of energy mainly on his own body, aided by that of domestic animals and to some extent by wind and water. The advantage of the human body as a machine is, of course, its infinite adaptability. There are still, and probably always will be, operations for which its unique co-ordination of mind and movement is essential. The disadvantage is its running expenses, which, compared with other forms of energy, are very high. Electrical energy equivalent to that which a man can produce can be had for a copper or so a day. Steam-power, on a large scale, is even cheaper. Unless a man's time is worth less than a penny or so an hour any mechanical operation which a machine can be designed to carry out can be performed much more economically by the use of one or other of the newly discovered forms of energy. Therein lies the explanation of the enormous increase in material wealth since the beginning of the so-called industrial era. It has been estimated that the average citizen of the United States was, just before the War, enjoying amenities equivalent to those which in classical times would have demanded the services of thirty slaves. There is no reason to suppose that the process has reached or even approached its limits.

There is, as everyone knows, a reverse side to this encouraging picture. The scrapping of obsolescent machinery is economically sound, but if the machine happens also to be a man the results are extremely distressing. It is perfectly true that on the balance and over a period of time the introduction of scientific sources of energy has found employment for far more workers than it has displaced. New physical discoveries have formed the basis of great new industries, and more workers with a far higher average output are now employed than ever before. The change-over period is, however, bound to cause intense suffering, unless the changes can be foreseen, and plans worked out to ease the transition. Only by constant and co-operative study and research can this be ensured.

The introduction of new forms of energy has, moreover, introduced more permanent changes into the structure of society. When each worker was his own power unit his work could be carried on effectively anywhere. Those were the days of the master craftsman, and a man could be, and frequently was, his own master. Steam-power, the first to be introduced, requires for its most economical application to be generated in large units. Moreover, the prime cost of installation was high. Workers had to go to the machine, and the factory system sprang into being. The early evils associated with that system have been largely eliminated, partly by enlightened legislation, partly by the gradual realization, as a result of psychological research; that dismal and unhealthy conditions of working are inimical to high output. A modern factory compares very favourably in its amenities with the average university research laboratory. The scale of living of the factory worker to-day is far higher than that of the home producer of a hundred years ago, while owing to ancillary scientific inventions such as the radio, the cinema, and quick cheap transport his facilities for enjoy. ment have been greatly enhanced; and owing to cheap energy his hours of work reduced. So much lies on the credit side; and, as I have said before, the limit has not yet been reached.
If, however, we believe that man does not live by bread alone, not even by bread and circuses, there may be another side to the question which at least merits investigation. What, if any, has been the effect on the men concerned of transforming a number of at any rate semi-independent skilled artisans into a body of factory operatives ? Assuming with Ruskin (a much discredited writer whom, I am told, few read to-day) that the true wealth of a nation lies in the quality of its individual citizens rather than in the mass of its material possessions, how does say five or six hours a day (supposing factory hours to be reduced to that number as they easily might be) spent in tending three or four automatic machines, or in any of the monotonous and mindless operations of a mass-production plant compare, from that point of view, with a somewhat longer daily period spent in an occupation where hand and brain are harmoniously employed together in the production of a finished article? Some preliminary research on these matters has been begun. Much more is needed. I would only add that should some decentralization prove to be desirable from a human point of view, the facilities are available to effect the transition without too great a loss of output. The transformation of steam into electrical energy has made the distribution of cheap energy to small production units an economically sound proposition.

The plea for the wider application of science in social affairs is often presented as if it were merely a matter of more research, and a fuller application of the results of research in everyday life. In the case of the biological sciences, from which direction the pressure mainly comes, this is undoubtedly true. 2 Freedom from disease, an ample sufficiency of good food, and appropriate clothing are fundamental necessities, and the biologists do well to insist on their ability to satisfy them. One would like to define the task of the physical sciences as the liberation of man from drudgery, so that he might be free to develop and enjoy his higher faculties, of which his creative ability is not the least. Owing to the, perhaps not unnatural, emphasis which has been placed on the accumulation of material wealth, it is doubtful whether the sum total of the drudgery of the world, of labour in which it is impossible to take either joy or pride, has been substantially reduced, though hours of work have been lessened, and can be still further reduced as the potentialities of physical research are more fully applied.

It would, I think, be an error to suppose that under any system of planning the volume of fundamental discovery in physical science could have been much increased, or the pace of its application to social purposes profitably accelerated. It is direction rather than speed which has been lacking. New powers have been exploited without a full consideration of their remoter repercussions upon society. To take perhaps an extreme but poignant example, the destruction of the heart of Coventry was implicit in those few brief seconds for which the first aeroplane lifted itself from the ground, but no warning was given, or at any rate was not heeded until too late.

The question of what constitutes 'the good life' is one of philosophy and religion, not of science. A wise society will take from the treasure house of science whatever it needs for the furtherance of its purposes, leaving unexploited, or at any rate severely controlled, what might be harmful. Society, however, needs, and is entitled to, the best advice on the more imme. diate, and the more distant consequences of the use. 
or neglect, of the opportunities provided by scientific discovery. Neither physicist, economist, nor sociologist is competent alone for this task. A combination of the three might do much to direct the stream of progress into the happiest channels.

\section{SOCIAL SCIENCE, STATISTICS AND POPULATION PROBLEMS}

\author{
BY D. CARADOG JONES \\ School of Social Sciences and Administration, \\ University of Liverpool
}

$\mathrm{T}$ HE vice-chancellor of one of our modern univer. sities has been heard to state on more than one occasion that he has failed to discover what is meant by social science. In a lesser man that might be taken as lack of appreciation of a field of knowledge fraught with immense consequences to mankind; but in this case it was no doubt intended as a criticism of social scientists because they have not defined with any precision the boundaries between their own and other sciences. That is not surprising in view of the rapid development of interest in the study of sociology. Interpreted widely, as it should be, it would include any branch of knowledge concerning man regarded as a social animal, in short, the study of human groups. Although, for convenience of observation, individuals may be isolated, interest centres in their social behaviour, their relationship to other individuals similar in many respects to themselves. But the diversity between them, in temperament, in outlook, in aims, is of even greater importance than the likeness. It is these differences, if not delicately handled, that produce strains and ruptures-strikes, wars and revolutions-in the body politic. There is an attraction in superficial remedies for such conditions, but they do not last. We spend our energy too often upon the perfecting of the machinery of social life, while neglecting the source and spring of all motivization : it is like designing a car, stream-lined and beautiful in all its parts, only to find that we have no suitable fuel to make it run smoothly. One of the most fundamental of the social sciences is psychology, because it explores the nature and causes of the divergences between individuals in their innermost citadel where they are most intimately revealed.

Another fundamental social science is philosophy, which creates harmony out of an assembly of seemingly discordant voices. This is achieved by discovering the purpose of life and so relating a diversity of means to a single-minded end. The individual converted, the right leader found, it can turn a mob into a disciplined army; but the purpose of the army is not to wage war upon some other faction. This social philosophy is essentially moral : it takes all the world as its parish, for in the realm of science there can be no partisanship. The warfare will not be against flesh and blood, but against ignorance and disease of mind and body, a ceaseless campaign systematically waged to get the best out of the rich natural resources available for the well-being of all mankind.

Assuming the philosopher to have contributed his share to the shaping of the new world, the political scientist will next be called upon to design regional and international instruments capable of transmuting the philosopher's ideal plan into realized fact; the public administrator will assume responsibility for the right use and control of these instruments ; and jurists will codify agreed rules to regulate social behaviour. As the curtain unfolds, the stage is seen to be set for actors almost without number, and each must play his part. The social historian warns us against the purchase of experience at too dear a price; he would have us profit by the mistakes committed in the past. The geographer deals with the reactions of human groups to their environment; it is his task to make an inventory of the raw materials latent in land and sea, to consider the most profitable use to be made of them, and to determine whether some areas are not too densely packed in view of their resources while others are starved of people to develop them adequately. Problems concerning the distribution and exchange of commodities come within the province of the economist; while the town planner contrives to apportion the land wisely to different uses, thereby preventing that haphazard building which has so frequently distorted the natural beauty of the countryside.

Hitherto we have failed to make a success of world government, not because we have lacked experts in all the social sciences mentioned, but because it has been nobody's business to survey the world as a whole and to co-ordinate the activities of these experts so that they work to a common plan. There has been another reason for failure: we have interpreted wealth in material terms and not in terms of human satisfaction. Economists and statisticians must take their share of the blame because, in comparing the standard of living of one class with another or the national income of one country with another, they have used money value as their measuring rodwith this much justification, that it seemed to be the only means of accurate measurement to hand. Yet, taken alone, it can be but a very imperfect index of what is really valuable in life. If we are to take true stock of a country's wealth, should we not start with the people who inhabit it? Apart from them, no other kind of wealth has sense or meaning.

So far this review has been in general terms. When we come down to practical details, we quickly discover large gaps in our machinery for making a satisfactory survey of the resources of even a small part of our own Empire, leaving other countries out of the account. Yot, to undertake such a continuous survey should be one of the main functions of the social scientist. Acting on the principle already enunciated, the most important feature of this stock taking would be to trace the trend of population, in size and character. It was well known before the present War began that the population of Great Britain, in common with that of most other European countries, was fast approaching a decline, and the War its. If will have gravely aggravated this condition. But population must always be considered in relation to the area occupied and to the stage of culture reached. With that in mind, the ques ion arisesHow shall optimum population be defined? And, having defined it, how shall it be achieved and how maintained ? Clearly the optimum is not merely a matter of size. More important than their number is the quality of the people who inhabit any country. But quality varies from class to class, from individual to individual, and even from age to age in the same individual. Hence, as a first step towards a definition of the optimum, it would be well to try to assess the size and quality of the actual population at some 